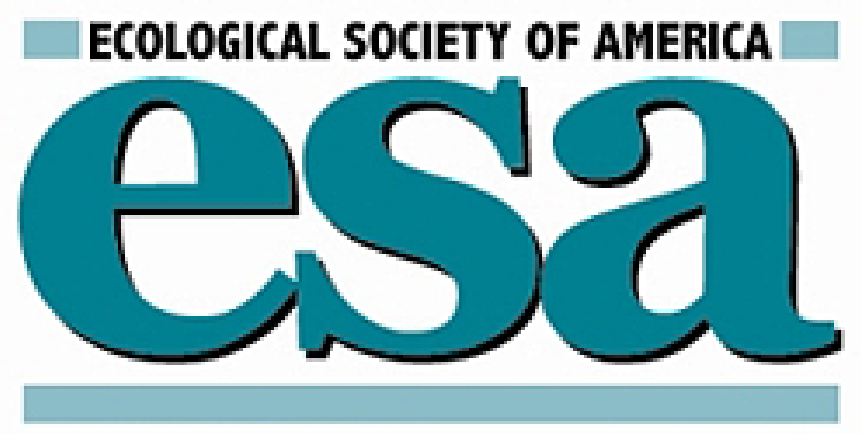

Cellulose Digestion and Assimilation by Three Leaf-shredding Aquatic Insects Author(s): R. L. Sinsabaugh, A. E. Linkins and E. F. Benfield

Source: Ecology, Vol. 66, No. 5 (Oct., 1985), pp. 1464-1471

Published by: Ecological Society of America

Stable URL: http://www.jstor.org/stable/1938009

Accessed: 13/03/2014 09:26

Your use of the JSTOR archive indicates your acceptance of the Terms \& Conditions of Use, available at http://www.jstor.org/page/info/about/policies/terms.jsp

JSTOR is a not-for-profit service that helps scholars, researchers, and students discover, use, and build upon a wide range of content in a trusted digital archive. We use information technology and tools to increase productivity and facilitate new forms of scholarship. For more information about JSTOR, please contact support@jstor.org. 
Copyright by the Ecological Society of America. R. L. Sinsabaugh, A. E. Linkins, and E. F. Benfield 1985. Cellulose Digestion and Assimilation by Three Leaf-shredding Aquatic Insects. Ecology 66:1464-1471. http:// dx.doi.org/10.2307/1938009

\title{
CELLULOSE DIGESTION AND ASSIMILATION BY THREE LEAF-SHREDDING AQUATIC INSECTS ${ }^{1}$
}

\author{
R. L. Sinsabaugh, A. E. Linkins, and E. F. Benfield ${ }^{2}$ \\ Department of Biology, Virginia Polytechnic Institute and State University, \\ Blacksburg, Virginia 24061 USA
}

\begin{abstract}
The capacity of three leaf-shredding aquatic insects, Pteronarcys proteus (Plecoptera: Pteronarcidae), Tipula abdominalis(Diptera: Tipulidae), and Pycnopsyche luculenta (Trichoptera: Limnephilidae), to digest and assimilate cellulose was investigated. Pteronarcys nymphs collected from two second-order woodland streams over a 14-mo period exhibited high levels of cellulolytic activity in their alimentary tracts, especially in the anterior gut. Similar though slightly lower activity levels were measured in Pycnopsyche guts. Cellulolytic activity in Tipula larvae collected from the streams during the same period was low to absent, and when present, was concentrated in the hindgut. General proteolytic activity was similar in the alimentary tracts of all three species.

Assimilation of uniformly labelled ${ }^{14} \mathrm{C}$-cellulose was determined by a dual-label technique, and assimilation efficiencies were estimated at $11.2 \%$ for Pteronarcys, $18.5 \%$ for Tipula, and $12.0 \%$ for Pycnopsyche. Confirmation that labelled digestion products passed the gut wall in two species was obtained by in vitro label transport experiments. Ion exchange fractionation of labelled digestion products crossing the gut wall showed that $>90 \%$ of the label was transported as organic acids and amino acids in Tipula, while $>40 \%$ of the label crossing the gut wall in Pteronarcys was neutral sugar. Based on the label experiments and published information, we hypothesize that Tipula relies mainly on microbial endosymbionts for cellulose hydrolysis, while Pteronarcys accomplishes hydrolysis largely by means of acquired microbial enzymes obtained through ingestion of microbially conditioned detritus. This study demonstrates the potential for certain leaf-shredding stream insects to derive nutritional benefit from plant polysaccharides, although not without microbial mediation.
\end{abstract}

Key words: cellulase; cellulose digestion; Pteronarcys; Pycnopsyche assimilation efficiency; shredder; stream; Tipula.

\section{INTRODUCTION}

Small streams of forested watersheds receive large inputs of allochthonous plant litter which may account for up to $99 \%$ of annual energy input (Fisher and Likens 1973). After leaching and rapid mineralization of labile compounds, leaf detritus is composed largely of lignin, cellulose, and hemicellulose (Suberkropp et al. 1976). Hence, a large fraction of the particulate organic matter available to woodland stream communities is in the form of refractory structural polymers. The rate at which energy flows through detritus-based stream communities is a function of the rate at which these refractory molecules can be hydrolyzed and assimilated by microand macroconsumers. The relative importance of detrital structural molecules and microbial biomass to detritivore nutrition is unclear, yet this relationship is fundamental to understanding energy flow in woodland streams.

Invertebrate detritivores that feed directly on dead leaves in woodland streams are designated shredders (Cummins 1973, Merritt and Cummins 1979). It is generally assumed that shredders gain the bulk of their nutrition from microbial biomass colonizing leaf detritus (e.g., Cummins 1974). This assumption is supported by feeding preference studies which have dem-

\footnotetext{
${ }^{1}$ Manuscript received 5 July 1984; revised 3 December 1984; accepted 4 December 1984.

${ }^{2}$ Address correspondence to this author.
}

onstrated that shredders selectively ingest leaf material with the highest degree of microbial conditioning (e.g., Triska 1970, Kaushik and Hynes 1971, Mackay and Kalff 1973, Anderson and Grafius 1975). Further, certain shredders may assimilate microbial biomass with efficiencies approaching 90\% (Berrie 1976). The observation that assimilation efficiencies for shredders feeding on leaf detritus appear to be generally $<25 \%$ (Vannote 1969, McDiffett 1970, Winterbourn and Davis 1976 , Iversen 1979, Golladay et al. 1983) and the notion that high carbon-to-nitrogen ratios render senescent plant material nutritionally incomplete (Cummins and Klug 1979) constitute additional supporting evidence. Finally, investigations directed toward finding enzymes essential for the digestion of leaf structural polysaccharides, e.g., cellulases, in the alimentary tracts of aquatic insects have met with mixed results (Bjarnov 1972, Monk 1976, Martin et al. 1980, 1981a, b).

The assumption of microbial biomass-dependent shredder nutrition is inconsistent with the observation that microbial biomass normally comprises only a small fraction $(<10 \%)$ of ingested detritus and probably is capable of providing only minimal $\mathrm{C}$ and $\mathrm{N}$ to support growth (Cummins and Klug 1979). For example, Baker and Bradnam (1976) found ingested bacteria were insufficient to support the nutritional needs of Simulium and Chironomus larvae, and suggested that detrital structural elements provided the bulk of energy to these detritivores. Cummins and Klug (1979) estimated only $8.3 \%$ of the observed growth of Tipula abdominalis 
could be attributed to microbial biomass associated with conditioned hickory leaves. Findlay et al. (1984) estimated that, at its maximum grazing rate, the freshwater isopod Lirceus obtained only $15 \%$ of its respired carbon from the bacterial biomass of decomposing leaves. Finally, the failure to detect significant cellulase activity in the alimentary tracts of aquatic insects (Bjarnov 1972, Monk 1976, Martin et al. 1980, 1981 $a, b$ ), does not preclude the possibility of cellulose digestion. For example, mammalian ruminants and certain cockroaches, termites, and beetles rely on microbial endosymbionts for cellulose digestion, but may exhibit little or no cellulase activity in their alimentary tracts (Hungate 1946, Wharton and Wharton 1965, Cruden and Markovetz 1979, Martin and Martin 1979, Bayon 1980, Bayon and Mathelin 1980).

It is clear that our understanding of aquatic detritivore nutrition is incomplete. However, the fact that leaf-shredding insects have been shown to ingest and assimilate both microbially "conditioned" and unconditioned leaves (Golladay et al. 1983) suggests that some component(s) of leaf material is a potential nutritional source for these insects. Soluble components, e.g., sugars and amino acids, would be excellent sources but, as mentioned, are rapidly leached, leaving the structural polysaccharides as potential nutritional sources. We approached the question of whether structural polysaccharides are potential sources for nutrition of three leaf-shredding aquatic insects in three ways: (1) assaying the gut tracts for cellulose hydrolyzing enzymes $(\beta$-1,4-glucanases); (2) feeding the insects radiolabelled cellulose substrate; (3) and evaluating the general types of labelled products crossing the gut wall.

\section{Materials ANd Methods \\ Collection sites}

Pteronarcys proteus Newman nymphs (Plecoptera: Pteronarcidae), and Tipula abdominalis (Say) larvae (Diptera: Tipulidae) and Pycnopsyche luculenta (Betten) larvae (Trichoptera: Limnephilidae) were collected from two second-order woodland streams: Guys Run (Goshen Wildlife Management Area, Rockbridge County, Virginia) and Little Stony Creek (Jefferson National Forest, Giles County, Virginia). Insects were collected by picking through natural leaf packs and debris dams. Pteronarcys nymphs ranging through several instars (15-32 mm long, 20-130 mg dry mass) were collected monthly over the period February 1979-June 1980. Tipula larvae (23-48 mm, 18-94 mg dry mass) and late instar Pycnopsyche larvae (15-22 mm, 13$28 \mathrm{mg}$ dry mass) were collected approximately monthly over the periods February 1979-June 1980 and February $1981-J u n e 1981$, respectively.

\section{Enzyme extraction}

Specimens were kept on ice and returned to the laboratory where they were frozen until analyzed. No de-

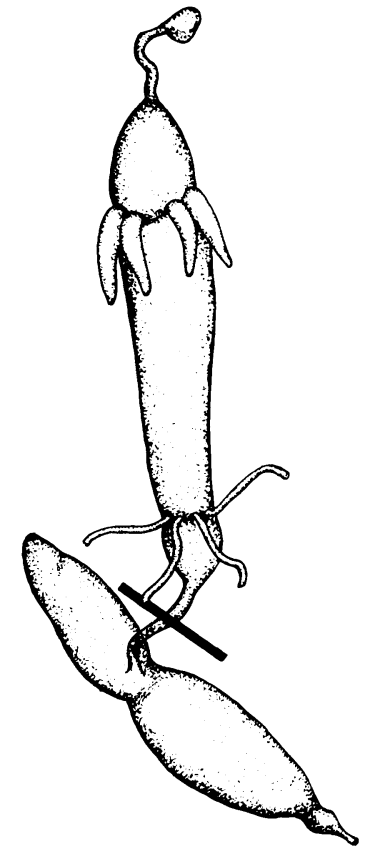

Tipula

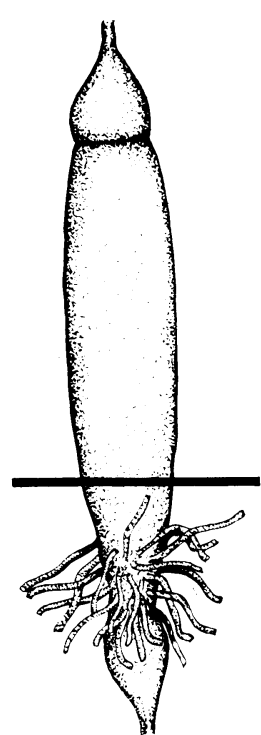

Pteronarcys
FIG. 1. Alimentary tracts of Tipula abdominalis and Pteronarcys proteus showing points at which the segments were divided.

tectable losses in enzyme activity were noted between frozen and fresh gut preparations. Thawed insects were dissected and guts were removed intact. Tipula and Pteronarcys tracts were divided into anterior (foregut and midgut) and posterior (hindgut) segments at the points indicated in Fig. 1. Because of their small size and fragile nature, Pycnopsyche guts were processed whole. Gut preparations from 10-20 individuals of each species were pooled and weighed. No effort was made to separate gut contents from tissue. Preparations were homogenized with aliquots of $20 \mathrm{mmol} / \mathrm{L}$ phosphate buffer ( $\mathrm{pH}$ 6.0) and centrifuged for $10 \mathrm{~min}$ at $100000 \mathrm{~m} / \mathrm{s}^{2}$. Supernatant solutions (extracts) were decanted and filtered through polyester cloth. Pellets were resuspended in phosphate buffer containing $1 \mathrm{~mol} / \mathrm{L}$ $\mathrm{NaCl}$, re-centrifuged, and the supernatant solutions retained. Extracts were kept refrigerated at $4^{\circ} \mathrm{C}$ until assayed.

\section{Enzyme assays}

Two glucanase assays were employed: a viscometric assay (Almin and Eriksson 1967) and a reducing sugar assay (Miller 1959), both using carboxymethylcellulose (CMC) as substrate. Procedural details of these assays are reported by Sinsabaugh (1980) and Sinsabaugh et al. (1981). The viscometric assay measures $\beta$-1,4-endoglucanase (endocellulase) activity in units proportional to absolute activity. Reducing sugar production (milligrams of glucose equivalents per hour) under sub- 
strate saturating conditions was used to quantify $\beta-1$, 4-exoglucanase (exocellulase) activity. Since these assays employ a soluble substrate, it cannot be determined whether glucanases capable of hydrolyzing crystalline cellulose were present. Traditionally, glucanases active against soluble cellulose are termed $C_{x}$-cellulases, while enzymes active toward crystalline cellulose are termed $\mathrm{C}_{1}$-cellulases. Soluble protein in the extracts were determined by a colorimetric procedure (Bradford 1976, Kley and Hale 1977) using Coomassie blue dye (Bio-Rad Laboratories 1977).

General proteoiytic activity was measured in gut extracts from all species. Using prevailing gut $\mathrm{pH}$, measured in situ with a $\mathrm{pH}$ microelectrode, excised guts from Pteronarcys and Pycnopsyche were extracted in pH 6.5 phosphate buffer, and Tipula in pH 11.5 carbonate buffer. Aliquots $(1.0 \mathrm{~mL})$ of extract were incubated for $45 \mathrm{~min}$ at $25^{\circ}$ in $1.0 \mathrm{~mL}$ of buffer and 20 mg of hide powder azure (Sigma Chemical Company). After incubation, suspensions were filtered and $1 \mathrm{~mL}$ of filtrate was pipetted into $2 \mathrm{~mL}$ of buffer for colorimetric analysis. Sample absorbance was measured at $595 \mathrm{~nm}$. One unit was defined as the amount of activity causing a change in absorbance of $0.001 \mathrm{~min} / \mathrm{mL}$ under the conditions of the assay.

\section{Decline of glucanase activity in alimentary tracts}

Field-collected Pteronarcys nymphs (19-37 mm, 26$189 \mathrm{~g}$ dry mass) were divided into two groups and placed in experimental tanks. After a 2-d acclimation period, one group was allowed to feed on conditioned leaves that had been collected along with the insects. The other group was provided with unconditioned red maple leaves that had been presoftened by soaking in $1 \mathrm{~mol} / \mathrm{L} \mathrm{HCl}$. Water and leaves in each tank were changed daily. After $5 \mathrm{~d}$, the experiment was terminated and the insects sacrificed. There was no mortality in either group over the experimental period and the presence of fecal pellets indicated both groups fed on the leaf detritus. Nymphs fed conditioned leaves were divided into four lots of seven individuals and those fed unconditioned leaves were divided into six lots of seven individuals. Excised guts within each lot were pooled, homogenized, and centrifuged at 100000 $\mathrm{m} / \mathrm{s}^{2}$. The supernatant solutions were assayed for cellulolytic activity as before.

A similar experiment was performed with fifth-instar Pycnopsyche larvae. One group was fed autoclaved red maple leaves for $5 \mathrm{~d}$ at $10^{\circ}$ with daily changes of water and leaves. A second group was fed stream-conditioned red maple leaves. There was evidence of extensive feeding by both groups, and no mortality was observed at the conclusion of the feeding period. Each group was subdivided into four lots of 10 larvae, from which guts were excised, extracted, and assayed for cellulolytic activity. This type of experiment was not conducted with Tipula because gut glucanase activity was consistently very low.

\section{Dual-label substrate feeding experiments}

A dual-label technique (Calow and Fletcher 1972) using uniformly labelled ${ }^{14} \mathrm{C}$-cellulose (ICN Chemical) and ${ }^{51} \mathrm{CrCl}_{3}$ was employed to investigate the capacity of Tipula and Pteronarcys to digest and assimilate purified cellulose. To remove hemicellulose and soluble impurities, the ${ }^{14} \mathrm{C}$-cellulose was treated as follows. The material was suspended in $200 \mathrm{~mL}$ of hot $\left(90^{\circ}-100^{\circ}\right)$ water for $30 \mathrm{~min}$, then collected on a $0.2-\mu \mathrm{m}$ membrane filter and rinsed three times with water. The remaining material was suspended in $200 \mathrm{~mL}$ of $10 \% \mathrm{NaOH}$ that had been degassed under vacuum for $30 \mathrm{~min}$. Nitrogen gas was continuously bubbled through the suspension. The $\mathrm{NaOH}$ was neutralized and the cellulose again collected on a membrane filter. The filter was repeatedly rinsed with hot water until no radioactivity washed through. The cellulose was then collected and dried at $50^{\circ}$.

Conditioned (incubated for 3-4 wk in aerated stream water) dogwood or maple leaf disks $(2.3 \mathrm{~cm}$ diameter $)$ were incubated for $48 \mathrm{~h}$ at $15^{\circ}$ in $100 \mathrm{~mL}$ of dechlorinated tapwater containing ${ }^{51} \mathrm{CrCl}_{3}$ with an activity level of $37 \mathrm{MBq}$. After labeling, the disks were leached for $24 \mathrm{~h}$ to remove extraneous label. Each leaf disk was dipped in a warm agar solution containing purified ${ }^{14} \mathrm{C}$ cellulose with an activity of $\approx 100 \mathrm{kBq}$. After allowing the agar to gel, individual disks were placed in a $100-$ mL disposable Petri dish containing $40 \mathrm{~mL}$ of dechlorinated tapwater. One insect was added to each dish, and the dishes were placed in an incubator at $15^{\circ}$.

If evidence of ingestion was apparent within $24 \mathrm{~h}$, the insects were removed, rinsed, and placed in a second dish containing $40 \mathrm{~mL}$ of water and unlabelled leaf disks. Uneaten portions of the dual-labelled disks were retained and dried. Feces were collected by filtering the dish contents through a $0.45-\mu \mathrm{m}$ glass fiber filter. Filtrate volume was recorded and filtrate samples were collected for later counting. Filters were dried and stored. After an additional $24 \mathrm{~h}$, insects were transferred to clean dishes containing fresh unlabelled disks. Feces and water samples were collected. This procedure was continued for two additional days. After the fourth fecal collection ( $96 \mathrm{~h}$ after the experiment began), the insects were sacrificed by immersing briefly in hot water, dried at $50^{\circ}$, and weighed.

At the conclusion of the experiment, filters, labelled leaf disks, and insects were homogenized separately and counted on a Beckman gamma counter to measure ${ }^{51} \mathrm{Cr}$ radioactivity. After gamma counting, samples were prepared for liquid scintillation counting by adding Aquasol (New England Nuclear) liquid scintillation cocktail and counted again on a liquid scintillation spectrometer to determine ${ }^{14} \mathrm{C}$ radioactivity. Water samples were treated similarly. Counting efficiencies were estimated by channels ratio curves and/or internal 
TABLE 1. Glucanase activity in gut extracts from freshly collected specimens of the three species. Data are means \pm 1 SE.

\begin{tabular}{|c|c|c|c|c|c|c|}
\hline \multirow[b]{2}{*}{ Species } & \multicolumn{3}{|c|}{ Endoglucanase } & \multicolumn{3}{|c|}{ Exoglucanase } \\
\hline & $N^{*}$ & $\begin{array}{l}\text { (Units/g } \\
\text { tissuet) }\end{array}$ & $\begin{array}{c}\text { (Units/mg } \\
\text { protein) }\end{array}$ & $N$ & $\begin{array}{c}\text { (Units/g } \\
\text { tissue) }\end{array}$ & $\begin{array}{c}\text { (Units/mg } \\
\text { protein) }\end{array}$ \\
\hline \multicolumn{7}{|l|}{ Pteronarcys } \\
\hline $\begin{array}{l}\text { Anterior } \\
\text { Posterior }\end{array}$ & $\begin{array}{l}14 \\
14\end{array}$ & $\begin{aligned} 4600 & \pm 480 \\
850 & \pm 90\end{aligned}$ & $\begin{array}{l}230 \pm 40 \\
100 \pm 14\end{array}$ & $\begin{array}{l}9 \\
9\end{array}$ & $\begin{array}{l}8.2 \pm 1.1 \\
1.8 \pm 1.0\end{array}$ & $\begin{array}{l}0.4 \pm 0.06 \\
0.2 \pm 0.09\end{array}$ \\
\hline Total & 14 & $4900 \pm 540$ & $200 \pm 30$ & 9 & $6.2 \pm 0.9$ & $0.4 \pm 0.06$ \\
\hline \multicolumn{7}{|l|}{ Tipula } \\
\hline $\begin{array}{l}\text { Anterior } \\
\text { Posterior }\end{array}$ & $\begin{array}{l}11 \\
11\end{array}$ & $\begin{array}{l}19 \pm 3 \\
73 \pm 20\end{array}$ & $\begin{array}{r}4 \pm 2 \\
13 \pm 6\end{array}$ & $\begin{array}{l}6 \\
6\end{array}$ & $\begin{array}{l}\text { ND } \ddagger \\
\text { ND }\end{array}$ & \\
\hline Total & 11 & $39 \pm 4$ & $7 \pm 4$ & 6 & ND & \\
\hline \multicolumn{7}{|l|}{ Pycnopsyche } \\
\hline Total & 10 & $1250 \pm 200$ & $164 \pm 10$ & 10 & $5.6 \pm 0.4$ & $0.8 \pm 0.1$ \\
\hline
\end{tabular}

* Each $N$ represents a group of pooled gut segments from 10-20 individuals.

$\dagger$ Tissue $=$ fresh gut tissue including contents.

$\ddagger N D=$ not detectable.

standards. ${ }^{14} \mathrm{C}:{ }^{51} \mathrm{Cr}$ ratios were computed for ingested and egested material, and assimilation efficiency was calculated as described by Calow and Fletcher (1972).

\section{Transport experiments}

In vitro label transport experiments were conducted to characterize the types of labelled compounds transported across gut walls. For this experiment, unpurified ${ }^{14} \mathrm{C}$-cellulose (mixture of $\approx 10 \%$ soluble sugar, $15 \%$ hemicellulose, and $75 \%$ cellulose), was used. After $\approx 2$ $\mathrm{h}$ of feeding on dual-labelled leaf disks, insects were anesthetized in $\mathrm{CO}_{2}$-saturated water and carefully dissected. Exposed guts were bathed in a saline solution (Griffiths and Tauber 1943) while the ends were double ligated with polyester thread. The ligated guts were excised and incubated in $4 \mathrm{~mL}$ of saline solution for 3 $\mathrm{h}$ at 15 . For Tipula, the anterior region (fore- and midgut) was incubated separately from the hindgut; Pteronarcys guts were incubated intact. Due to their size and fragility, we were unsuccessful at excising intact guts from Pycnopsyche, so no information on transport products was collected. After incubation, samples of the saline solutions were tested for the presence of ${ }^{51} \mathrm{Cr}$ by gamma counting. An absence of gamma emission from the samples was taken as evidence that gut integrity was maintained through excision and incubation.

The saline solutions were passed through anion (BioRad AG 50W-X8, 200-400 mesh) and cation (BioRad AG 1-X8, 200-400 mesh [38-75 $\mu \mathrm{m}]$ ) ion exchange resins arranged in series at room temperature. Resins were prepared after Atkins and Canvin (1971) and slurried into $0.8 \times 6.0 \mathrm{~cm}$ columns (total bed volume $3 \mathrm{~cm}^{3}$ ). Three fractions were collected from the columns. A neutral fraction (containing neutral sugars) was eluted with $25 \mathrm{~mL}$ of distilled water. Basic and acidic fractions, containing amino acids and organic acids, respectively, were eluted with $25 \mathrm{~mL}$ of $2 \mathrm{~mol} / \mathrm{L}$ $\mathrm{HCl}$ and $25 \mathrm{~mL}$ of $6 \mathrm{~mol} / \mathrm{L}$ formic acid, respectively.
The presence of sugars in the neutral fraction was confirmed by the Nelson-Somogyi reducing sugar assay (Nelson 1944). The three fractions were neutralized and mixed with Aquasol for liquid scintillation counting. Quench-corrected counts were used to compute the proportion of label transported in each fraction.

\section{RESULTS}

\section{Enzyme activity}

Glucanase activity was detected in Pteronarcys extracts at relatively high levels but with considerable variation among sampling dates (Table 1). Glucanase activity in gut extracts from Tipula was much lower than that recorded for Pteronarcys and was frequently undetectable. Activity in Pycnopsyche was intermediate, though not statistically distinct from Pteronarcys (Student's $t$ test, $P<.05$ ). In addition to quantity, the distribution of glucanase activity within the alimentary tracts differed between species (Table 1). In Pteronarcys, activity was confined primarily to the anterior gut, while the reverse was true for Tipula. The distribution of activity along the gut of Pycnopsyche is unknown. While glucanase activity ranged over two orders of magnitude, gut protease activity was similar among the three species (Table 2).

When groups of Pteronarcys or Pycnopsyche were deprived of conditioned leaf material in 5-d laboratory feeding experiments, the levels of endo- and exoglucanase activity showed statistically significant declines compared to other groups fed conditioned leaves (Table 3). In Pteronarcys, the average decline in activity was $41 \%$ for endoglucanase and $35 \%$ for exoglucanase. Average declines in Pycnopsyche were $61 \%$ for endoglucanase and $46 \%$ for exoglucanase.

\section{Substrate digestion and label transport}

The dual-label radioisotope experiments demonstrated that all three insects have the capacity to digest 
TABLE 2. Proteolytic activity in gut extracts from fresh specimens of the three species. Data are means \pm 1 SE.

\begin{tabular}{lrll}
\hline \hline \multicolumn{1}{c}{ Species } & $N^{*}$ & $\begin{array}{c}\text { Units/g } \\
\text { tissue } \dagger\end{array}$ & $\begin{array}{c}\text { Units/mg } \\
\text { protein }\end{array}$ \\
\hline Pteronarcys & 10 & $650 \pm 40^{\mathrm{a}} \ddagger$ & $51 \pm 6^{\mathrm{a}}$ \\
Tipula & 8 & $480 \pm 20^{\mathrm{b}}$ & $67 \pm 9^{\mathrm{a}}$ \\
Pycnopsyche & 12 & $520 \pm 50^{\mathrm{b}}$ & $67 \pm 14^{\mathrm{a}}$ \\
\hline
\end{tabular}

${ }^{*}$ Each $N$ represents a group of pooled gut segments from 10-20 individuals.

$\dagger$ Tissue $=$ fresh gut tissue including contents.

₹ Values with the same letter are not significantly different (ANOVA, Duncan's Multiple Range Test, $P<.004$ ).

and assimilate purified cellulose (Table 4). Assimilation efficiency was significantly higher in Tipula than in the other two species. The in vitro incubations of ligated guts revealed considerable difference in the relative distribution of labelled digestion products transported across the gut wall by Pteronarcys and Tipula (Table 5).

\section{DisCUSSION}

Our experiments demonstrated that all three insect species have the ability to digest and assimilate plant cell wall polysaccharides including cellulose. However, differences in the magnitude of gut glucanase activity, types of digestive products crossing the gut wall, gut morphology, and $\mathrm{pH}$, suggest Tipula and Pteronarcys may employ different digestive strategies. There are three potential sources of cellulose-degrading enzymes associated with animals: tissue-level synthesis, microbial symbionts, and "acquired" enzyme from the diet.

Tissue-level synthesis of both $C_{1}$ and $C_{x}$ cellulases has been reported for a variety of aquatic and terrestrial invertebrates, especially among mollusks, annelids, and crustaceans (e.g., Nielsen 1962, Yokoe and Yasumasu 1964, Elyakova 1972). Among insects, however, tissue-level synthesis of both $\mathrm{C}_{1}$ and $\mathrm{C}_{\mathrm{x}}$ enzymes has been reported only in certain termites (Potts and Hewitt 1973) and cockroaches (Wharton and Wharton 1965). While we cannot rule out some tissue-level cellulase production by either Tipula or Pteronarcys, we feel it is unlikely that either can synthesize all the enzyme components required for complete hydrolysis of crystalline cellulose. Among the remaining alternatives, we hypothesize that Pteronarcys utilizes significant amounts of acquired microbial glucanase for cellulolysis, while digestion and assimilation of cellulose by Tipula is mainly through microbial symbionts.

Acquired microbial cellulases have been reported in some insects. For example, Martin and Martin (1978, 1979) found the termite Macrotermes depends on a cultivated fungus for a supply of cellulase. Kukor and Martin (1983) found that the woodwasp Sirex cyaneus used cellulase acquired by ingestion of a fungus, Amylostereum chailletii, for the digestion of wood tissue. Among freshwater invertebrates, Bärlocher (1982) reported the use of acquired microbial cellulase by the amphipod Gammarus fossarum. In the case of cellulase found in the gut of Pteronarcys, there are several lines of evidence pointing to acquired microbial cellulases. First, we previously demonstrated that microbial cellulases were ubiquitous on decaying leaves in the stream from which nymphs used here were collected (Sinsabaugh et al. 1981). Since fungal cellulases are very stable enzymes (Reese 1977, Linkins et al. 1978, Martin 1979) any detritivore whose gut environment is of the proper $\mathrm{pH}$, redox potential, and ionic strength (Martin 1979) could benefit from ingested enzymes. We have no data on the redox potential or ionic strength of gut fluids in Pteronarcys, but in situ gut $\mathrm{pH}$ measurements on individuals collected over the study period revealed a mean anterior gut $\mathrm{pH}$ of 6.4 (range $6.2-6.4, n=14$ ) and a mean hindgut $\mathrm{pH}$ of 7.2 (range $7.1-7.4, n=14)$. The gut $\mathrm{pH}$, especially the anterior section where most of the cellulase activity was found, is quite compatible with a $\mathrm{pH}$ profile generated for cellulases solubilized from conditioned leaves (Sinsabaugh et al. 1981). A second point is that cellulase activity declines when nymphs are deprived of a constant supply of conditioned leaf material. In fact, we have observed almost complete loss of cellulase activity after a few weeks in nymphs fed filter paper. Evidence mitigating against an endosymbiotic origin for the high levels of cellulase activity in Pteronarcys also supports an acquired glucanase hypothesis. The nymphs have simple tubular guts that lack the distinctive fermentation chambers found in most animals harboring cellulolytic endosymbionts (Martin 1979). In addition, there appears to be no permanent gut flora in the Pteronarcys alimentary tract (Meitz 1974, Cummins and Klug 1979). Finally, our in vitro digestion experiments showed that a significant fraction $(40 \%)$ of the radiolabelled digestive products crossed the gut wall as neutral sugar. We would not expect to find significant amounts of free sugar either in the gut or passing the gut wall were endosymbionts a major pathway available for cellulolysis (Bayon and Mathelin 1980). But with $60 \%$ of the label crossing the gut wall as organic and amino

TABLE 3. Comparison of glucanase activity in individuals fed conditioned or unconditioned leaf material after $5 \mathrm{~d}$. Data are means $\pm 1 \mathrm{SE}$.

\begin{tabular}{lccc}
\hline \hline Species & $N$ & $\begin{array}{c}\text { Endoglucanase } \\
\text { (Units/g } \\
\text { tissue*) }\end{array}$ & $\begin{array}{c}\text { Exoglucanase } \\
\text { (Units/g } \\
\text { tissue) }\end{array}$ \\
\hline $\begin{array}{c}\text { Pteronarcyst } \\
\text { Conditioned }\end{array}$ & 4 & $3990 \pm 240$ & $7.7 \pm 0.7$ \\
$\quad$ Unconditioned & 6 & $2350 \pm 320$ & $5.0 \pm 0.9$ \\
Pycnopsyche & & & \\
$\quad$ Conditioned & 4 & $355 \pm 22$ & $1.3 \pm 0.1$ \\
$\quad$ Unconditioned & 4 & $140 \pm 16$ & $0.7 \pm 0.1$ \\
\hline
\end{tabular}

* Tissue $=$ fresh gut tissue including contents.

$\dagger$ Differences in activity between conditioned and unconditioned treatments were significant in all cases $(t$ test, $P<$ $.05)$. 
TABle 4. Assimilation efficiency for labelled cellulose (mean $\pm 1 \mathrm{SE})$.

\begin{tabular}{lcc}
\hline \hline Species & $\begin{array}{c}\text { No. indi- } \\
\text { viduals }\end{array}$ & $\begin{array}{c}\text { Assimilation } \\
\text { efficiency }\end{array}$ \\
\hline Tipula & 8 & $18.5 \pm 0.8^{\mathrm{a}, *}$ \\
Pteronarcys & 9 & $11.2 \pm 0.9^{\mathrm{b}}$ \\
Pycnopsyche & 6 & $12.0 \pm 0.9^{\mathrm{b}}$ \\
\hline
\end{tabular}

* Values with the same letter are not significantly different (ANOVA, Duncan's Multiple Range Test, $P<.001$ ).

acids, some microbial metabolism of liberated sugars obviously occurred. Based on gut morphology and previous microbiological studies cited above, we presume the microbes responsible to be associated with leaf material in the diet.

Our case for endosymbionts as a source of cellulolysis in the alimentary tract of Tipula is supported by several lines of evidence. First, the gut of Tipula is compartmentalized and the hindgut contains a distinctive rectal lobe similar to that described by Wigglesworth (1974) as a fermentation chamber. Both the midgut and hindgut were reported to contain a dense bacterial flora (Meitz 1974, Klug and Kotarski 1980). Bacteria in the midgut lumen were similar to those attached to ingested detritus, but those associated with the hindgut lumen and wall appeared to compose a community similar in form and development to the endosymbiotic communities found in termites and higher animals (Klug and Kotarski 1980). Second, the near absence of detectable cellulase activity in the guts of tipulid larvae is consistent with an endosymbiotic mode of cellulolysis. As pointed out by Bayon and Mathelin (1980), bacterial cellulases tend to remain tightly bound to the cell walls and do not enter the gut milieu. Such enzymes would not be detected by normal enzyme assays of the sorts employed here. A lack of detectable cellulase activity in tipulid gut may also be related to prevailing pH. Martin et al. (1980) reported the tipulid gut to be alkaline, ranging from $\approx \mathrm{pH} 8$ in the foregut to $\mathrm{pH} 11$ in the midgut. Our own measurements are similar: 7.2-10.2 in the anterior gut and 6.5-7.5 in the hindgut. Since $\mathrm{pH}$ optima for cellulase activity are in the range 4-6 (Reese 1977, Sinsabaugh et al. 1981), little activity would be expected in the tipulid gut even if acquired enzymes were present. Finally, our in vitro digestion studies showed that $>90 \%$ of the labelled digestion products were organic or amino acids (Table 5), presumably derived from microbial metabolism of the labelled substrate. In similar experiments using radiolabelled cellulose and ligated gut segments from the terrestrial beetle Oryctes nasicornis, Bayon and Mathelin (1980) reported an absence of labelled hexose sugars in both gut milieu and incubation media, but found a variety of labelled organic acids. They attributed these findings to a rapid conversion of sugars liberated from the labelled cellulose by gut endosymbionts. In ongoing research with Tipula larvae, microbial metabolites from hindgut flora appear to be important sources of energy for these insects (R. W. Merritt, personal communication).

The third insect we examined, Pycnopsyche, appears to be similar to Pteronarcys with respect to gut physiology. The $\mathrm{pH}$ of the anterior gut is $6.1-6.4$ and that of the posterior gut ranges 6.4-6.7. There was detectable glucanase activity present in the gut over the study period, and activity was shown to decline when larvae were deprived of conditioned leaf material. The gut is essentially a straight tube; however, the hindgut of a related species, $P$. guttifer, is enlarged and has been shown to have attached microbiota (Cummins and Klug 1979). We were unable to perform the in vitro digestion experiments with $P$. luculenta due to the fragility of the gut and thus can speculate no further as to the mechanisms of cellulolysis.

Proteolytic activity was similar in the alimentary tracts of Pteronarcys, Tipula, and Pycnopsyche, despite differences in gut morphology and pH. Martin et al. (1980) suggested that the digestive tract of Tipula $a b$ dominalis is adapted for efficient protein digestion to the exclusion of detrital structural polysaccharides. This suggestion was based on observations that the Tipula gut is highly alkaline, which optimizes proteolysis, but lacks detectable cellulase activity. We have shown that cellulase activity is not necessarily a good indicator of an ability to digest cellulose; i.e., Tipula, with virtually no detectable cellulolytic activity, had the highest assimilation efficiency of purified cellulose of the three insects tested. In a later paper, Martin et al. (1981b) reported gut proteolytic activity of Pteronarcys californica and Pteronarcys picteii to be in the same range as that of Tipula abdominalis, which agrees with our data for Pteronarcys and Tipula. In the absence of definitive assimilation experiments, there appears to be

TABLE 5. Fractionation of in vitro transported cellulose digestion products.

\begin{tabular}{|c|c|c|c|}
\hline Species & $\begin{array}{l}\text { No. indi- } \\
\text { viduals }\end{array}$ & Fraction & $\begin{array}{l}\text { Mean per- } \\
\text { cent of } \\
\text { transport- } \\
\text { ed prod- } \\
\text { ucts }\end{array}$ \\
\hline \multicolumn{4}{|l|}{ Pteronarcys } \\
\hline Whole gut & 5 & $\begin{array}{l}\text { neutral } \\
\text { acidic } \\
\text { basic }\end{array}$ & $\begin{array}{l}42^{\mathrm{a}, *} \\
32^{\mathrm{a}, \mathrm{b}} \\
26^{\mathrm{b}}\end{array}$ \\
\hline \multicolumn{4}{|l|}{ Tipula } \\
\hline Anterior gut & 5 & $\begin{array}{l}\text { neutral } \\
\text { acidic } \\
\text { basic }\end{array}$ & $\begin{array}{r}8^{\mathrm{a}} \\
50^{\mathrm{b}} \\
42^{\mathrm{b}}\end{array}$ \\
\hline Posterior gut & 5 & $\begin{array}{l}\text { neutral } \\
\text { acidic } \\
\text { basic }\end{array}$ & $\begin{array}{r}7^{\mathrm{a}} \\
41^{\mathrm{b}} \\
52^{\mathrm{b}}\end{array}$ \\
\hline
\end{tabular}

* Values with the same letter are not significantly different (ANOVA, Duncan's Multiple Range Test, $P<.05$; data were arcsine transformed, Sokal and Rohlf 1969). 
little reason to suppose that Tipula is more efficient at digesting protein than is Pteronarcys or Pycnopsyche.

It is important to note that the purified substrate used in our experiments may be more digestible than native cellulose in leaves. Cellulose in plant fiber varies in degree of crystallization and lignification, both of which can limit access to the glycosyl bonds by glucanases (Reese 1977, Crawford 1981). Our estimates of cellulose assimilation efficiency compare favorably to estimates of overall assimilation efficiency for Tipula and Pteronarcys. McDiffett (1970) reported assimilation efficiencies from $8-16 \%$ for Pteronarcys scotti feeding on detritus. Golladay et al. (1983) found dry matter assimilation efficiency of Pteronarcys proteus ranged from 10 to $22 \%$ depending on leaf type and conditioning time. S. W. Golladay (personal communication) also found that dry matter assimilation by Tipula abdominalis ranged as high as $30 \%$.

Our study demonstrates the potential for some leafshredding stream insects to derive nutritional benefit from plant cell wall polysaccharides, although not without microbial mediation in the form of microbial exoenzymes or endosymbiotic associated hydrolysis and fermentation. While microbes colonizing leaf tissue undoubtedly supply essential nutrients like vitamins, sterols, and protein (Cummins and Klug 1979), the role of structural polysaccharides in the nutrition of shredders should not be ignored.

\section{ACKNOWLEDGMENTS}

Funding was provided in part by the FMC Corporation through the Virginia State Water Control Board. We acknowledge J. C. Servaites for advice on fractionation of label digestion products and M. J. Klug for advice on labelled substratc purity.

\section{Literature Cited}

Almin, K. E., and K. E. Eriksson. 1967. Enzymic degradation of polymers: I. Viscometric method for the determination of enzymic activity. Biochimica et Biophysica Acta 139:238-247.

Anderson, N. H., and E. Gaffius. 1975. Utilization and processing of allochthonous material by stream Trichoptera. Internationale Vereinigung für theoretische und ange wandte Limnologie, Verhandlungen 19:3083-3088.

Atkins, C. A., and D. T. Canvin. 1971. Photosynthesis and $\mathrm{CO}_{2}$ evolution by leaf disks: gas exchange, extraction, and ion-exchange fractionation of ${ }^{14} \mathrm{C}$-labelled photosynthetic products. Canadian Journal of Botany 49:1225-1234.

Baker, J. H., and L. A. Bradnam. 1976. The role of bacteria in the nutrition of aquatic detritivores. Oecologia (Berlin) 24:95-104.

Bärlocher, F. 1982. The contribution of fungal enzymes to the digestion of leaves by Gammarus fossarum Koch (Amphipoda). Oecologia (Berlin) 52:1-4.

Bayon, C. 1980. Volatile fatty acids and methane production in relation to anaerobic carbohydrate fermentation in $\mathrm{Or}$ cytes nasicornis larvae (Coleoptera: Scarabeidae). Journal of Insect Physiology 26:833-840.

Bayon, C., and J. Mathelin. 1980. Carbohydrate fermentation and by-product absorption studied with labelled cellulose in Orcytes nasicornis larvae (Coleoptera: Scarabeidae). Journal of Insect Physiology 26:833-840.
Berrie, A. D. 1976. Detritus, microorganisms and animals in fresh water. Pages 323-338 in J. M. Anderson and A. Macfadyen, editors. The role of terrestrial and aquatic organisms in decomposition processes. Blackwell, Oxford, England.

Bio-Rad Laboratories. 1977. Bio-Rad protein assay. Technical Bulletin 1051, Bio-Rad Laboratories, Richmond, California, USA.

Bjarnov, N. 1972. Carbohydrases in Chironomus, Gammarus, and some Trichoptera larvae. Oikos 23:261-263.

Bradford, M. M. 1976. A rapid and sensitive method for the quantitation of microgram quantities of protein utilizing the principle of protein-dye binding. Analytical Biochemistry 72:248-254.

Calow, P., and C. R. Fletcher. 1972. A new radiotracer technique involving ${ }^{14} \mathrm{C}$ and ${ }^{51} \mathrm{Cr}$, for estimating the assimilation efficiencies of aquatic, primary consumers. Oecologia (Berlin) 9:155-170.

Crawford, R. L. 1981. Lignin degradation and transformation. John Wiley and Sons, New York, New York, USA.

Cruden, D. L., and A. J. Markovetz. 1979. Carboxymethyl cellulose decomposition by intestinal bacteria of cockroaches. Applied Environmental Microbiology 38:369-372.

Cummins, K. W. 1973. Trophic relations of aquatic insects. Annual Review of Entomology 18:183-206.

- 1974. Structure and function of stream ecosystems. BioScience 24:631-641.

Cummins, K. W., and M. J. Klug. 1979. Feeding ecology of stream invertebrates. Annual Review of Ecology and Systematics 10:147-172.

Elyakova, L. A. 1972. Distribution of cellulases and chitinases in marine invertebrates. Comparative Biochemistry and Physiology 43B:67-70.

Findlay, S., J. L. Meyer, and P. J. Smith. 1984. Significance of bacterial biomass in the nutrition of a freshwater isopod (Lirceus sp.). Oecologia (Berlin) 63:38-42.

Fisher, S. G., and G. E. Likens. 1973. Energy flow in Bear Brook, New Hampshire: an integrative approach to stream ecosystem metabolism. Ecological Monographs 43:421-439.

Golladay, S. W., J. R. Webster, and E. F. Benfield. 1983. Factors affecting food utilization by a leaf shredding aquatic insect: leaf species and conditioning time. Holarctic Ecology 6:157-162.

Griffiths, J. T., and O. E. Tauber. 1943. Effects of $\mathrm{pH}$ and various concentrations of sodium, potassium, and calcium chloride on muscular activity of the isolated crop of Periplaneta americana (Orthoptera). Journal of General Physiology 26:541-558.

Hungate, R. E. 1946. The symbiotic utilization of cellulose. Journal of the Elisha Mitchell Society 62:9-24.

Iversen, T. M. 1979. Laboratory energetics of larvae of Sericostoma personatum (Trichoptera). Holarctic Ecology 2: $1-5$.

Kaushik, N. K., and H. B. N. Hynes. 1971. The fate of dead leaves that fall into streams. Archiv für Hydrobiologie 68: 465-515.

Kley, H. V., and S. Hale. 1977. Assay for protein by dye binding. Analytical Biochemistry 81:485-487.

Klug, M. J., and S. Kotarski. 1980. Bacteria associated with the gut tract of larval stages of the aquatic cranefly, Tipula abdominalis (Diptera: Tipulidae). Applied Environmental Microbiology 40:408-416.

Kukor, J. J., and M. M. Martin. 1983. Acquisition of digestive enzymes by siricid woodwasps from their fungal symbiont. Science 220:1161-1163.

Linkins, A. E., R. M. Atlas, and P. Gustin. 1978. Effect of surface applied crude oil on soil and vascular plant root respiration, soil cellulase and aryl hydrocarbon hydroxylase at Barrow, Alaska. Arctic 31:355-365.

Mackay, R. J., and J. Kalff. 1973. Ecology of two related 
species of caddis fly larvae in the organic substrates of a woodland stream. Ecology 54:499-511.

Martin, M. M. 1979. Biochemical implications of insect mycophagy. Biological Reviews 54:1-21.

Martin, M. M., J. J. Kukor, J. S. Martin, D. L. Lawson, and R. W. Merritt. 1981a. Digestive enzymes of the larvae of three species of caddisflies (Trichoptera). Insect Biochemistry 5:501-505.

Martin, M. M., and J. S. Martin. 1978. Cellulose digestion in the midgut of the fungus-growing termite Macrotermes natalensis: the role of acquired digestive enzymes. Science 199:1453-1455.

Martin, M. M., and J. S. Martin. 1979. The distributior and origins of the cellulolytic enzymes of the higher termite, Macrotermes natalensis. Physiological Zoology 52:11-21.

Martin, M. M., J. S. Martin, J. J. Kukor, and R. W. Merritt. 1980. The digestion of protein and carbohydrate by the stream detritivore, Tipula abdominalis (Diptera:Tipulidae). Oecologia (Berlin) 46:360-364.

Martin, M. M., J. S. Martin, J. J. Kukor, and R. W. Merritt. $1981 b$. The digestive enzymes of detritus-feeding stonefly nymphs (Plecoptera:Pteronarcidae). Canadian Journal of Zoology 59:1947-1951.

McDiffett, W. F. 1970. The transformation of energy by a stream detritivore Pteronarcys scotti (Plecoptera). Ecology 51:975-988.

Meitz, A. K. 1974. Alimentary tract microbiota of aquatic invertebrates. Thesis. Michigan State University, East Lansing, Michigan, USA.

Merritt, R. W., and K. W. Cummins. 1979. An introduction to the aquatic insects of North America. Kendall/Hunt, Dubuque, Iowa, USA.

Miller, G. L. 1959. Use of dinitrosalicyclic acid reagent for determination of reducing sugar. Analytical Chemistry 31: 426-428.

Monk, D. C. 1976. The distribution of cellulose and dietary components and $\mathrm{pH}$ of the gut in the amphipod, Gammarus pulex (L.). Freshwater Biology 7:431-440.

Nelson, N. 1944. A photometric adaptation of the Somogyi method for the determination of glucose. Journal of Biological Chemistry 153:375-380.

$\rightarrow$ Nielsen, C. O. 1962. Carbohydrases in soil and litter invertebrates. Oikos 13:200-215.
Potts, R. C., and P. H. Hewitt. 1973. The distribution of intestinal bacteria and cellulase activity in the harvester termite Trinervitermes trinervoides (Nasutitermitinae). Insectes Sociaux 20:215-220.

Reese, E. T. 1977. Degradation of polymeric carbohydrates by microbial enzymes. Pages 311-317 in F. A. Loewus and B. C. Runeckles, editors. The structure, biosynthesis, and degradation of wood. Plenum, New York, New York, USA.

Sinsabaugh, R. L. 1980. Distribution of microbial and macroinvertebrate cellulolytic activity in relation to leaf processing in a headwater stream. Thesis. Virginia Polytechnic Institute and State University, Blacksburg, Virginia, USA.

Sinsabaugh, R. L., E. F. Benfield, and A. E. Linkins. 1981. Cellulase activity associated with decomposition of leaf litter in a woodland stream. Oikos 36:184-190.

Sokal, R. R., and F. J. Rohlf. 1969. Biometry. W. H. Freeman, San Francisco, California, USA.

Suberkropp, K. F., G. L. Godshalk, and M. J. Klug. 1976. Changes in the chemical composition of leaves during processing in a woodland stream. Ecology 57:720-727.

Triska, F. J. 1970. Seasonal distribution of aquatic hyphomycetes in relation to the disappearance of leaf litter from a woodland stream. Dissertation. University of Pittsburgh, Pittsburgh, Pennsylvania, USA.

Vannote, R. L. 1969. Detrital consumers in natural systems. Pages 20-23 in K. W. Cummins, editor. American Association for the Advancement of Science Symposium Technical Report Number 7, Institute of Water Research, Michigan State University, East Lansing, Michigan, USA.

Wharton, D. R. A., and M. L. Wharton. 1965. The cellulase content of various species of cockroaches. Journal of Insect Physiology 11:1401-1405.

Wigglesworth, V. B. 1974. The principles of insect physiology. Chapman and Hall, London, England.

Winterbourn, M. J., and S. F. Davis. 1976. Ecological role of Zelandopsyche ingens in a beech forest stream ecosystem. Australian Journal of Marine and Freshwater Research 27:197-215.

Yokoe, Y., and I. Yasumasu. 1964. The distribution of cellulases in invertebrates. Comparative Biochemistry and Physiology 13:323-338. 